\title{
Role of Micro Nutrients Bio- Fortification in Agriculture: A Review
}

\author{
Muhammad Adnan ${ }^{1 *}$, Basharat Abbas ${ }^{1}$, Muhammad Asif ${ }^{1}$, Muhammad Sikander Hayyat ${ }^{1}$, Ali Raza ${ }^{1}$, Bilal Ahmad \\ Khan ${ }^{1}$, Mudassir Hassan ${ }^{1}$, Muhammad Awais Bashir Khan ${ }^{1}$, Muhammad Danish Toor ${ }^{2}$ and Mozna Khalid ${ }^{3}$
}

${ }^{1}$ Department of Agronomy, University of Sargodha, Pakistan

${ }^{2}$ Department of Soil and Environmental Sciences, University of Sargodha, Pakistan

${ }^{3}$ Sulaiman Bin Abdullah Aba Al-Khail, Centre for Interdisciplinary Research in Basic and Applied Sciences, Pakistan

Submission: April 24, 2020; Published: May 08, 2020

*Corresponding author: Muhammad Adnan, Department of Agronomy, College of Agriculture, University of Sargodha, Pakistan

\section{Abstract}

Calcium, Zinc and iron are in the list of essential plant nutrients for growth and development. Bio fortification or foliar fertilization is very important strategy for crop management, which is very useful for obtaining maximum crop yield and quality. Bio fortification is used as a way of providing additional doses of macro- and micro-nutrients, stimulants, plant hormones and other favorable elements. The present review describes the role of calcium, zinc and iron in agricultural crop production and impact of bio-fortification of nutrients on crops.

Keywords: Calcium; Zinc; Iron; Bio fortification

\section{Introduction}

WHO reports describes that lack of micronutrients are major threat to world population [1]. Bio fortification word is a greek work "bios" means "life" and Latin word "fortificare" means "making strong". It is a process of improving bioavailable in edible portions in plants [2]. Calcium (Ca) performs major roles in plant growth processes, necessary for cell walls and structure of plant, maintains the structure of plant tissues and acts as an element that maintains cells structure. Calcium deficiency stops development of new root and shoot tissue (extension and cell division). Calcium is constituent which regulates transport of nitrogen and relations with phosphorus and potassium [3]. Zinc is a micronutrient which takes part in many physiological functions, its improper supply can effect badly crop growth and yield. Zinc deficiency is major problem in all over world and it effects all type of soils including calcareous, sandy, loam and peat. Soils having high percentage of phosphorus and silicon are also expected to zinc deficiency. Deficiency of zinc can affect plants negatively by stunting growth, stop tillering process, smaller leaves and their chlorosis, extending crop maturity period, sterility of spikelet and poor quality of harvested products [4]. Iron is a major micronutrient for every living organism because it performs crucial function in metabolic processes such as composition of DNA, respiration and process of photosynthesis. Moreover, many other metabolic pathways are stimulated by iron. It is a prosthetic group constituent of many enzymes. Iron performs a primary function in numerous physiological and biochemical plant functions. It works as a component of many important enzymes such as cytochromes in electron transport chain, therefore it is necessary in many and biological tasks. Iron also takes part in chlorophyll synthesis, so it is needed for maintaining structure and function of chloroplast.

\section{Role of Calcium in growth of crop plants}

Calcium (Ca) performs major roles in plant growth processes, necessary for cell walls and structure of plant, maintains the structure of plant tissues and acts as an element that maintains cells structure. Calcium deficiency stops development of new root and shoot tissue (extension and cell division). Calcium is constituent which regulates transport of nitrogen and relations with phosphorus and potassium [3]. [5] reported that the fortification performs a fundamental role in growth of crop plants. Among all nutrients calcium is a main nutrient involved in plant growth. Plant uptake calcium as $\mathrm{Ca}^{2+}$, is necessary for plants growth and fruit development [6,7]. Calcium makes resistant the plants against diseases due to its character in cell wall [8]. Calcium performs important biochemical functions and supports many metabolic processes and also activates numerous enzymatic systems, thus takes part in proper plant development [9]. Calcium performs vital role in membrane stability and cell integrity. From 
the whole plant leaves have highest concentration of calcium contents, highest concentration of calcium in plant leaves may be due to the formation of calcium pectate in the middle lamella of plant cells. Calcium is weak in mobility in plants, so it is not possible to re-translocate from old shoot tissues to young tissues and its transportation from xylem to other organs that are poor in transpiration rate. Calcium is an element which takes part in transport of nitrogen and interaction with potassium and phosphorus. Abiotic stresses often lead to increase in free calcium in the cytoplasm of plant cells, which promotes to gene expression that activates biochemical functions which allow the plant to adjust adverse conditions. Thus, calcium enables the plant to incorporate adverse conditions such as high temperature, water stress, salinity and chilling injury, by taking part in regulatory mechanisms.

[10] reported that salt toxicity which contains osmotic and ionic ingredients both that can badly disturb growth of root and shoot organs. Sodium ion $\left(\mathrm{Na}^{+}\right)$uptake throughout plasma membrane is highly fast on physiologic impacts in extracellular as well as intracellular locations. Sodium restricts attachment of calcium ion $\left(\mathrm{Ca}^{2+}\right)$ with plasma membrane; it stops inflow while increases outflow of calcium ion $\left(\mathrm{Ca}^{2+}\right)$, and drains interior stocks of calcium ion $\left(\mathrm{Ca}^{2+}\right)$ from endomembrane. These amendments are suggested in cell $\mathrm{Ca}^{2+}$ homeostasis which is primary reflexes to salt stress that are received by roots. Salt could directly shrink quantity of calcium ion $\left(\mathrm{Ca}^{2+}\right)$ being shifted to leaves, when calcium ion $\left(\mathrm{Ca}^{2+}\right)$ activity drops and sodium ion $\left(\mathrm{Na}^{+}\right)$activity rises in apoplasm of plant leaf cells. This calcium ion $\left(\mathrm{Ca}^{2+}\right)$ signal could be transferred to foliage if water supply signals are not proceeding. Signals through hormones are to be expected secondary in nature and can be initiated by $\mathrm{Na}^{+}$-related disorder of roots calcium ion $\left(\mathrm{Ca}^{2+}\right)$ homeostasis. Amelioration impacts of supplementary calcium ion $\left(\mathrm{Ca}^{2+}\right)$ on salt stress are exerted by blocking $\mathrm{Na}^{+}-$ related deviations in cell calcium ion $\left(\mathrm{Ca}^{2+}\right)$ homeostasis. Arshi et al. (2006) investigated the photosynthesis process, growth rate, sennoside quantity and yield parameters of senna crop plants under treatments of $\mathrm{CaCl}_{2}, \mathrm{NaCl}$ and combination of both. $\mathrm{NaCl}$ application causes significant reduction in stomatal conductance, pod biomass, leaf area, photosynthesis process, and percentage $\&$ yield of sennoside. On other hand positive results were found on application of $\mathrm{CaCl}_{2}$. [11] Studied the impacts of calcium on crop growth of potato. Results showed that application of calcium significantly increased tuber yield and plant height in both varieties of potato (shenkola and in gera). On other hand tuber yield and plant height was not much differ in both varieties sprayed with all levels of individual calcium chloride. Hence it is concluded that calcium chloride and calcium nitrate application at different levels affect plant growth and tuber yield of potato. [12] investigated special impacts of UV-B radiation and $\mathrm{CaCl}_{2}$ on enrichment of carotenoid content in germinated kernels of corn. $\mathrm{CaCl}_{2}$ treatments and UV-B radiation had positive effects on antioxidant activity and carotenoid content. Moreover, the contents of carotenoid were greater when under treatments was combination of UV-B radiation and $\mathrm{CaCl}_{2}$. Our results explained that UV-B radiation can increase carotenoid contents and activity of antioxidant enzymes. Furthermore, $\mathrm{CaCl}_{2}$ can also improve carotenoid contents and reduces photo oxidative injury that is caused by UV-B radiation.

\section{Role of Zinc in growth of crop plants}

Zinc is a micronutrient which takes part in many physiological functions; its improper supply can effect badly crop growth and yield. Zinc deficiency is major problem in all over world and it effects all type of soils including calcareous, sandy, loam and peat. Soils having high percentage of phosphorus and silicon are also expected to zinc deficiency. Deficiency of zinc can affect plants negatively by stunting growth, stop tillering process, smaller leaves and their chlorosis, extending crop maturity period, sterility of spikelet and poor quality of harvested products [4]. [13] conducted an experiment to investigate impacts of biofortification of forage sorghum with zinc under different nitrogen levels. He reported that bio-fortification of zinc and nitrogen improved height of plant, leaf area, fresh forage yield, dry matter, protein content $\%$ and zinc content of plant but decreased the acid detergent fiber, neutral detergent fiber, and ash percentage. Application of $10 \mathrm{~kg} \mathrm{ha}^{-1}$ zinc and $120 \mathrm{~kg} \mathrm{ha}^{-1}$ nitrogen showed an average increase of 7.3 and $18.6 \%$ in green fodder yield while 12.1 and $15.8 \%$ in dry matter yield, respectively. Similarly, 6.1 and $7.5 \%$ increase in crude protein was noted over control. In conclusion, $\mathrm{Zn}$ and $\mathrm{N}$ gave the best results in term of quality and yield of forage sorghum.

[14] conducted an experiment to study the effects of micronutrient such as zinc, iron, boron, manganese and. Results of their study clearly showed that use of micronutrients (copper, zinc, iron, boron and manganese etc.) significantly increased the plant growth because these micronutrients take part in important metabolic roles in plant growth and development, therefore are called an essential trace element or micronutrients. Zinc performs certain physiological functions in all living processes, like as the maintenance of structure and functions in integrity of biological membranes and assistance of protein synthesis and energy production, gene expression, enzymes structure and Kreb's cycle, also has a progressive impact on crops yield. Therefore, zinc strongly improves soil quantitative and qualitative yield of crops.

[15] investigated that proper fertilization of crops with zinc is a major factor for maximizing quality and yield of agricultural products. Zinc is such micronutrient which essentially required for ordinary profitable growth of crop plants, and that crop also improves health of animals as well as humans that intake as a divalent cation $\left(\mathrm{Zn}^{2+}\right)$ from plants. Zinc performs key role in plants metabolism. This nutrient plays a key role on many enzymes building such as: isomerase, dehydrogenases and aldolase. Zinc also helps in energy production and Kreb's cycle. Zinc deficiency 
greatly reduces crop quality and yields in soil. [16] conducted an experiment in which he treated Olive trees (Olea europaea L.) with gibberellic acid and zinc sulphate. Both nutrients were applied when fruit attained $70 \%$ of their final size. They reported that fruit yield considerably increased by application of $\mathrm{GA}_{3}$ and $\mathrm{ZnSO}_{4}$ rather than without any treatment. Most effective treatment was $\mathrm{GA}_{3}+$ zinc sulphate spray at rate $0.5 \%$ \& $30 \mathrm{ppm}$ concentration which improved yield than control and other concentrations. Thus, this treatment clearly enhanced olive fruit growth, and also enhanced fruit size and yield of every individual tree and enable for improve its economic importance.

[17] studied the consequences of $\mathrm{Zn}$ supply in subsoil in three varieties of Brassica napus and one variety of Brassica juncea in a pots experiment that was managed in glasshouse. The top growing portion of soil was enriched with zinc in entire treatments however zinc was applied or deleted from soil basement. Mixing zinc in basement greatly improved root length in lower zone, outstandingly reduced number of degraded and follow hollow pods per plant and considerably improved no. of productive pods/plant, seed biomass, seed ratio/pod and overall seed production. Zinc in subsoil also improved zinc quantity and zinc content in seed portion, amount of $\mathrm{Zn}$ uptake both by seed and foliage portion.

\section{Role of Iron in growth of crop plants}

Iron is a major micronutrient for every living organism because it performs crucial function in metabolic processes such as composition of DNA, respiration and process of photosynthesis. Moreover, many other metabolic pathways are stimulated by iron. It is a prosthetic group constituent of many enzymes. Iron performs a primary function in numerous physiological and biochemical plant functions. It works as a component of many important enzymes such as cytochromes in electron transport chain, therefore it is necessary in many and biological tasks. Iron also takes part in chlorophyll synthesis, so it is needed for maintaining structure and function of chloroplast. [18] reported that iron is compulsory element for enzymatic system which carryout oxidation reduction reactions and electron transport chain in plants, maintaining of chloroplasts structure, chlorophyll synthesize, and enzyme activation, that also regulates energy process which includes photosynthesis, respiration, reduction of nitrates and sulphates, these reactions are necessary in energy producing in plants for their development and reproduction [19].

[20] reported that different enzymes magnesium, iron and manganese are compounds in biogenesis of terpenoids. $\mathrm{FeSO}_{4}$, $\mathrm{MgSO}_{4} \& \mathrm{MnSO}_{4}$ were applied through spray on foliage of two levels $(0.2 \%$ and $0.3 \%)$ before 30 days from harvesting on rates of terpenoids and phenolic compounds in matured mango and fruits were examined. All the different rates considerably improved lupeol in peel fruits as in comparison to control conditions and larger lupeol concentration noted in pith when fruit was treated with $\mathrm{FeSO}_{4} @ 0.3 \%$. Every nutrient application
@ $0.3 \%$ considerably improved total carotenoid concentration in pith. Mangiferin in pith was substantially greater in treatment of $\mathrm{FeSO}_{4} @ 0.2 \%$, magnesium and manganese against with control condition and @ 0.3\%. Accumulation of caffeic acids, gallic and ferulic in peel, chlorogenic acid in pulp and peel was maximum when fruit was treated with iron sulphates @0.2\%. [21] stated that impacts of fertilization of nitrogen and iron nutrients on growth and yield of soybean. They reported that poor seed production of soybean may result due to deficiency of iron intake and decreased biological nitrogen fixation due to higher $\mathrm{pH}$ and bicarbonate of soils. Starter dose of nitrogen greatly enhanced plant leaf area and biomass at flowering stage on the other hand application of iron fertilizer affect early growth parameters. Bio fortification highly increased number of pods and seed yield at final stage in both years. This research proved that application of iron and nitrogenous fertilizers positively increased yield and growth parameters of soybean crop in soil having high concentration of bicarbonates and $\mathrm{pH}$. [22] studied the effects of seed priming and foliar fertilization of zinc and iron on quality and yield of forage maize. Trail was held in greenhouse and also in field during two consecutive years. Seed priming and foliar spraying was performed in six treatments. Results explained that both forms of iron fertilization greatly increased chlorophyll concentration in leaves, compared to other treatments and control conditions. In both farms of zinc increased dry biomass, height of plant, crude protein contents, total dissolve carbohydrates.

\section{Effects of combination of nutrients on growth of crop plants}

[23] studied the impacts of combination of foliar fertilization of calcium, iron and zinc sulfate on different reproductive growth parameters strawberry fruit. Results indicated that calcium, iron \& zinc sulfate highly increased leaf area, dry weight, root length of strawberry plant. Foliar application of zinc sulfate at $150 \mathrm{mg} \mathrm{l}^{-1}$, iron at $1000 \mathrm{mgl}^{-1}$ and calcium at $10 \mathrm{mM}$ enhanced total number of flowers, primary and secondary weight of fruit. Maximum concentration of total soluble solids, titratable acidity and ascorbic acid was achieved in fruits treated with zinc sulfate at rate of $150 \mathrm{mg} / \mathrm{l}$ and minimum concentration was achieved in control condition. [24] examined the impacts of foliar fertilization of micronutrients. They reported that $0.6 \%$ Calcium improved height of plant, no. of primary and secondary branches, no. leaves/plant, leaf area per plant, and fruit per plant. All other treatments improved all growth parameters in comparison with controlled conditions. Comparing the interaction between calcium, zinc and boron showed positive results for most of all attributes. Therefore, it is recommended that bio fortification of calcium and zinc in combination through foliar spray improved growth and fruit production of tomato. [25] conducted field trail to sort out possible effects of foliar spray of nutrients with different ratio on tomato crop at vegetative growth, flowering stage and overall yield. The data was recorded of all important parameters plant height, plant girth, days to first flowering, days 
to mature, days to first fruiting, fruit weight, fruit biomass/plant, no. of fruits/plant, length of, diameter of fruit and yield per ha. Even though all treatments showed a positive impact on growth of plant, flowering and yield but combination of nutrients $(\mathrm{Fe}, \mathrm{Zn})$ showed most significant effects on all parameters in experiment as compared to control condition.

\section{Effects of foliar fertilization on crops}

The best technique for maximum utilization necessary plant nutrients is through foliar application to attain highest economic production. Soil application technique is very easy and cast effective but fertilizer required in larger quantity [21]. A larger quantity of fertilizer is lost through seepage in soil application technique. However foliar fertilization saves fertilizer losses which cause through seepage and this technique is also quickly available to plant. Application through soil mostly based on soil analysis but foliar technique based on plant analysis. Soil and foliar can also apply at once for better results. If the foliar technique is combined with fungicides, herbicides and insecticides yield could be improved and cast application can also reduce [26]. [27] conducted an experiment to investigate effects of different fertilization techniques on forage sorghum. They reported that foliar application is more efficient than the all other different methods of supplying nutrient to the crops. Moreover, foliar application method had positive results on no. of leaves, height of plants, fresh yield, no. of tiller, dry leaf yield, leaf area, leaf weight/stem weight ratio, dry stem biomass, total dry yield and ash percentage. Fertilization method play key role for attaining best absorption of nutrients. This study elaborated that, iron, zinc and manganese had positive effects on quality and quantity of sorghum fodder. All yield and quality parameters showed positive results by foliar biofortification of zinc plus iron. Maximum tillers were recorded by combined effects of Zinc and iron.

[28] examined impacts of bio fortification of zinc on seed biomass of rice crop. Different eight levels of zinc sulphates were used in the experiment. All were applied through foliar spray at different rice growth stages. The obtained seeds germinated to calculate effects of seed zinc on seedling growth. Foliar application of zinc greatly improved paddy zinc concentration only when applied at flowering stage and larger increase was noted at repeating application. A positive correlation is found between zinc concentration and seed germination. Therefore, zinc ratio in grains of rice could be effectively improved by bio fortification of zinc after flowering.

[29] arranged a research on calcareous soils to check the effects of micronutrient deficiency especially zinc and iron. Analysis of his study showed that a great yield losses were occurred by nutrient deficiency, mostly micronutrients on calcareous soils throughout last 10 years. Pakistan's 90\% soils are lacking in micronutrients, especially iron and zinc. This research explains that foliar fertilization technique is very effective to overcome these deficiencies in different crops. This research proved that foliar fertilization of zinc, copper and iron on cotton crop can effectively improve the seed-cotton yield. Foliar fertilization also developed the nutrient ratio in leaves as compared to soil applied fertilizers. This agronomic method increased economic yield of cotton crop and quality. [30] organized a research to check response of bio fortification through foliar spray on wheat. The experiment contained one foliar spray of nutrients at tillering, two spray at jointing and three spray at booting stage. Foliar fertilization increased all parameter clearly such as number of grains numbers, grain weight, spikes numbers, biological yield and grain yield. Maximum results of all parameters were recorded by three foliar spray of nutrients. Higher yield of grains was noted on two foliar treatments of nutrients on jointing but statistically it was similar with three foliar sprays nutrient. So it was concluded that wheat yield and yield related components could be improved by three sprays of nutrient on foliage. [31] arranged, two experiments to determine impacts of foliar fertilization of nutrients. All treatments were comprised of bio fortification of micronutrients zinc, iron and their combination. There source was zinc suphate and ferrous sulphate at ratio of $0.35 \%$, with control and different time of treatments. First on stem elongation, 2nd on flowering and 3rd on both stages. The analysis explained that yield of flower, oil ratio, and their yield significantly improved by spray on foliage of zinc and iron as compared to no treatment. So it may be prescribed that foliar fertilization of zinc and iron can greatly improve flowering process and content of chamomile's oil in calcareous soils.

\section{Conclusion}

It is concluded from the above review that bio fortification is the best technique to full fill the nutrient requirements of plants with immediate response. Furthermore, it saves the recourses also and improves crop production..

\section{References}

1. WHO (2007) Micronutrient deficiency: iron deficiency anaemia. Geneva: WHO.

2. Meena RS, Gogoi N, Kumar S (2017) Alarming issues on agricultural crop production and environmental stresses. Journal of Cleaner Production 142(2): 3357-3359.

3. Leon C, Leon J, Leon JM (1992) U.S. Patent No. 5,095,887. Washington, DC: U.S. Patent and Trademark Office.

4. Hafeez B, Khanif YM, Saleem M (2013) Role of zinc in plant nutrition. American Journal of Experimental Agriculture 3(2): 374379.

5. El Habbasha SF, Faten MI (2015) Calcium: Physiological function, deficiency and absorption. International Journal of Chem Tech Research 8(12): 196-202.

6. McLaughlin SB, Wimmer R (1999) Tansley Review No. 104 Calcium physiology and terrestrial ecosystem processes. The New Phytologist 142(3): 373-417. 
7. Parra Terraza S, Villarreal Romero M, Sanchez-Pena P, CorralesMadrid JL, Hernandez-Verdugo S (2008) Effect of calcium and osmotic potential of the nutritive solution on the tomato blossom-end rot, mineral composition and yield. Interciencia 33(6): 449-456.

8. Torres-Olivar V, Villegas-Torres OG, Domínguez-Patiño ML, Sotelo-Nava H, Rodríguez-Martínez A, et al. (2014) Role of nitrogen and nutrients in crop nutrition. Journal of Agricultural Science and Technology. 4(1): 29-33.

9. Mengel K, Kirkby EA (1987) Principles of plant nutrition. Bern. International Potash Institute 26(1): 687-695.

10. Rengel Z (1992) The role of calcium in salt toxicity. Plant, Cell and Environment 15(6): 625-632.

11. Seifu YW, Deneke S (2017) Effect of Calcium Chloride and Calcium Nitrate on Potato. Journal of Horticulture 4(3): 22-28.

12. He W, Wang Y, Dai Z, Liu C, Xiao Y, et al. (2019) Effect of UV-B radiation and a supplement of $\mathrm{CaCl}_{2}$ on carotenoid biosynthesis in germinated corn kernels. Food Chemistry 278(2): 509-514.

13. Ahmad W, Tahir M, Ahmad R, Ahmad, R (2018) Agronomic biofortification of fodder sorghum with zinc under different levels of nitrogen. Sains Malaysiana 47(6): 1269-1276.

14. Mousavi SR, Galavi M, Rezaei M (2013) Zinc (Zn) importance for crop production. International Journal of Agronomy and Plant Production 4(1): 64-68.

15. Mousavi SR (2011) Zinc in crop production and interaction with phosphorus. Australian Journal of Basic and Applied Sciences 5(9): 1503-1509.

16. Ramezani S, Shekafandeh A (2009) Roles of gibberellic acid and zinc sulphate in increasing size and weight of olive fruit. African Journal of Biotechnology 8(24): 29-37.

17. Grewal HS, Zhonggu L, Graham, RD (1997) Influence of subsoil zinc on dry matter production, seed yield and distribution of zinc in oilseed rape genotypes differing in zinc efficiency. Plant and Soil 192(2): 181189.

18. Rout GR, Sahoo S (2015) Role of iron in plant growth and metabolism. Reviews in Agricultural Science 3(2): 1-24.

19. Eskandari H (2011) The importance of iron (Fe) in plant products and mechanism of its uptake by plants. Journal of Applied Environmental and Biological Sciences 1(10): 448-452.

20. Vithana MDK, Singh Z, Johnson SK (2018) Levels of terpenoids, mangiferin and phenolic acids in the pulp and peel of ripe mango fruit influenced by pre-harvest spray application of $\mathrm{FeSO}_{4}\left(\mathrm{Fe}^{2+}\right), \mathrm{MgSO}_{4}$ $\left(\mathrm{Mg}^{2+}\right)$ and $\mathrm{MnSO}_{4}\left(\mathrm{Mn}^{2+}\right)$. Food chemistry 256(3): 71-76.

21. Caliskan S, Ozkaya I, Caliskan ME, Arslan M (2008) The effects of nitrogen and iron fertilization on growth, yield and fertilizer use efficiency of soybean in a Mediterranean-type soil. Field Crops Research 108(2): 126-132.

22. Sharifi R, Mohammadi K, Rokhzadi A (2016) Effect of seed priming and foliar application with micronutrients on quality of forage corn ( $\mathrm{Zea}$ mays L.). Environmental and Experimental Biology 14(2): 151-156.

23. Kazemi M (2014) Influence of foliar application of iron, calcium and zinc sulfate on vegetative growth and reproductive characteristics of strawberry cv.'Pajaro'. Trakia Journal of Sciences 12(1): 21-26.

24. Haleema B, Rab A, Hussain SA (2018) Effect of calcium, boron and zinc foliar application on growth and fruit production of tomato. Sarhad Journal of Agriculture 34(1): 19-30.

25. Roosta HR, Hamidpour M (2011) Effects of foliar application of some macro-and micro-nutrients on tomato plants in aquaponic and hydroponic systems. Scientia Horticulturae 129(3): 396-402.

26. Fageria NK, Filho MB, Moreira A, Guimaraes CM (2009) Foliar fertilization of crop plants. Journal of Plant Nutrition 32(6): 10441064.

27. Soleymani A, Shahrajabian MH (2012) Effects of different levels of nitrogen on yield and nitrate content of four spring onion genotypes. International Journal of Agriculture and Sciences 4(4): 179-182.

28. Boonchuay P, Cakmak I, Rerkasem B, Prom-U-Thai C (2013) Effect of different foliar zinc application at different growth stages on seed zinc concentration and its impact on seedling vigor in rice. Soil science and plant nutrition 59(2): 180-188.

29. Yaseen M, Ahmed W, Shahbaz M (2013) Role of foliar feeding of micronutrients in yield maximization of cotton in Punjab. Turkish Journal of Agriculture and Forestry 37(4): 420-426.

30. Arif M, Chohan MA, Ali S, Gul R, Khan S (2006) Response of wheat to foliar application of nutrients. Journal of Agricultural and Biological Science 1(4): 30-34

31. Nasiri Y, Zehtab-Salmasi S, Nasrullahzadeh S, Najafi N, GhassemiGolezani K (2010) Effects of foliar application of micronutrients ( $\mathrm{Fe}$ and $\mathrm{Zn}$ ) on flower yield and essential oil of chamomile (Matricaria chamomilla L.). Journal of Medicinal Plants Research 4(17): 17331737.

\section{Your next submission with Juniper Publishers} will reach you the below assets

- Quality Editorial service

- Swift Peer Review

- Reprints availability

- E-prints Service

- Manuscript Podcast for convenient understanding

- Global attainment for your research

- Manuscript accessibility in different formats

(Pdf, E-pub, Full Text, Audio)

- Unceasing customer service

Track the below URL for one-step submission https://juniperpublishers.com/online-submission.php 